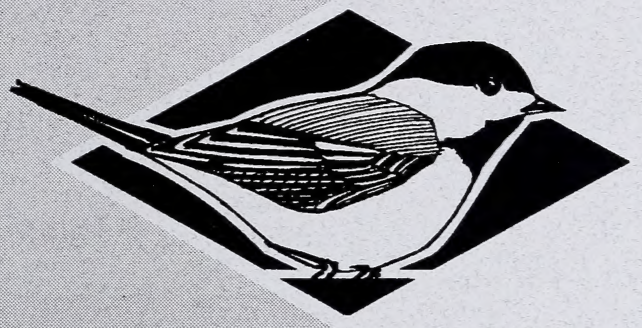

\title{
Status of the . \\ Eastern Short-horned Lizard (Phrynosoma douglassii brevirostre) in Alberta
}

\author{
Janice D. James \\ Anthony P. Russell \\ G. Lawrence Powell
}

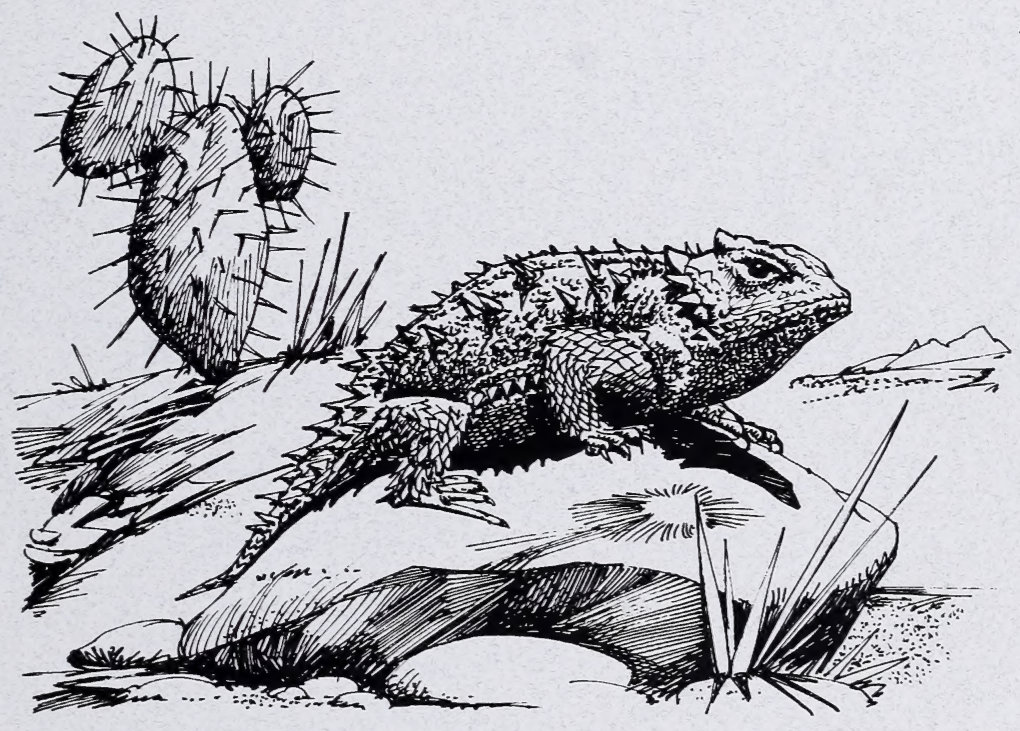

Alberta Wildlife Status Report No. 5 
Digitized by the Internet Archive in 2015

https://archive.org/details/statusofeasterns00jame 


\title{
Status of the Eastern Short-horned Lizard (Phrynosoma douglassii brevirostre) in Alberta
}

\author{
Janice D. James \\ Anthony P. Russell \\ G. Lawrence Powell
}

Alberta Wildlife Status Report No. 5

Published By:
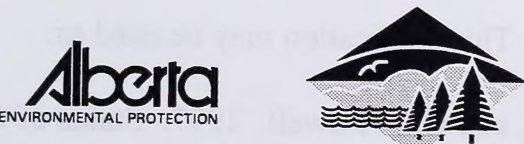
Publication No. T/368

ISBN: 0-7732-5130-8

ISSN: $1206-4912$

Series Editor: David R. C. Prescott

Illustrations: Brian Huffman

For copies of this report, contact:

Information Centre - Publications

Alberta Environmental Protection

Natural Resources Service

Main Floor, Bramalea Building

9920 - 108 Street

Edmonton, Alberta, Canada T5K 2M4

Telephone: (403) 422-2079

\section{OR}

Communications Division

Alberta Environmental Protection

$\# 100,3115$ - 12 Street NE

Calgary, Alberta, Canada T2E 7J2

Telephone: (403) 297-3362

This publication may be cited as:

James, J. D., A. P. Russell, and G. L. Powell. 1997. Status of the Eastern Short-horned Lizard (Phrynosoma douglassii brevirostre) in Alberta. Alberta Environmental Protection, Wildlife Management Division, Wildlife Status Report No. 5, Edmonton, AB. 20 pp. 


\section{PREFACE}

Every five years, the Wildlife Management Division of Alberta Natural Resources Service reviews the status of wildlife species in Alberta. These overviews, which have been conducted in 1991 and 1996, assign individual species to "color" lists which reflect the perceived level of risk to populations which occur in the province. Such designations are determined from extensive consultations with professional and amateur biologists, and from a variety of readily-available sources of population data. A primary objective of these reviews is to identify species which may be considered for more detailed status determinations.

The Alberta Wildlife Status Report Series is an extension of the 1996 Status of Alberta Wildlife review process, and provides comprehensive current summaries of the biological status of selected wildlife species in Alberta. Priority is given to species that are potentially at risk in the province (Red or Blue listed), that are of uncertain status (Status Undetermined), or which are considered to be at risk at a national level by the Committee on the Status of Endangered Wildlife in Canada (COSEWIC).

Reports in this series are published and distributed by the Wildlife Management Division of Alberta Environmental Protection, and are intended to provide detailed and up-to-date information which will be useful to resource professionals for managing populations of species and their habitats in the province. The reports are also designed to provide current information which will assist the proposed Alberta Endangered Species Conservation Committee to identify species that may be formally designated as endangered or threatened under the Alberta Wildlife Act. To achieve these goals, the reports have been authored and/or reviewed by individuals with unique local expertise in the biology and management of each species. 


\section{EXECUTIVE SUMMARY}

The Eastern Short-horned Lizard (Phrynosoma douglassii brevirostre) is Alberta's only native lizard species. Scattered populations of these small, well-camouflaged lizards are found on sparsely-vegetated slopes of canyons and coulees in the extreme southeastern parts of the province. Short-horned Lizards have recently been moved to the "Blue List" of species which may be at risk in Alberta. The species has also been designated as "vulnerable" by the Committee on the Status of Endangered Wildlife in Canada (COSEWIC). This report was prepared as a review of current information relevant to the determination of the status of this species in Alberta.

In Alberta, Eastern Short-horned Lizards are at the northern extreme of the species' range. Population size and trends have not been accurately assessed for the province, but the species occurs at low densities relative to adjacent populations in Montana and other areas of the western United States, and a recent report suggested that populations in Alberta declined over the 1980s. Populations in Alberta are generally found in areas that are free from extensive human disturbance, and are probably limited by natural factors such as climate. However, there are a number of human-related factors which may affect the viability of populations on a local scale. These factors include urbanization, motorized traffic, agricultural operations, and activities associated with oil and gas development.

Populations of the Eastern Short-horned Lizard in Alberta do not appear to be immediately at risk of extirpation. However, the small, sparsely-distributed population in Alberta, coupled with potential threats to lizard habitat, make the species susceptible to population declines in the future. Additional field research is needed to clarify these threats, and to better define the species' status in this province. 


\section{ACKNOWLEDGEMENTS}

Thanks are due to Wendy Hodges (Texas Horned Lizard Conservation Society, University of Austin), to Laura Friis (B.C. Fish and Wildlife) for helpful comments, and to Dennis Flath (Montana Fish, Wildlife and Parks) for providing information on the species outside of Alberta. Also, the cooperation and interest of the Laidlaw family has been greatly appreciated over the years. The comments of Kelly Zamudio (University of California, Berkeley), were also pertinent. Leo Dubé (Alberta Natural Resource Service, Lethbridge) also provided access to additional information. Finally, thank-you's must also go out to Andy Didiuk (Canadian Wildlife Service), Steve Brechtel and David Prescott (Alberta Natural Resources Service) for commenting on the draft version of this report, Delinda Ryerson (Alberta Natural Resources Service) for editorial assistance, and Jane Horb for producing the maps.

Preparation of this report was funded by the Wildlife Management Enhancement Fund of Alberta Natural Resources Service and the Alberta Conservation Association. 


\section{TABLE OF CONTENTS}

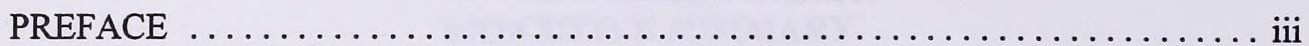

EXECUTIVE SUMMARY $\ldots \ldots \ldots \ldots \ldots \ldots \ldots \ldots \ldots \ldots \ldots \ldots \ldots \ldots \ldots \ldots$ iv

ACKNOWLEDGEMENTS $\ldots \ldots \ldots \ldots \ldots \ldots \ldots \ldots \ldots \ldots \ldots \ldots \ldots \ldots \ldots \ldots$

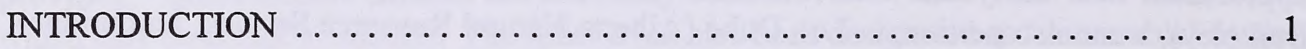

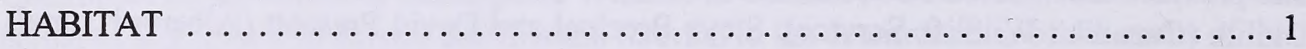

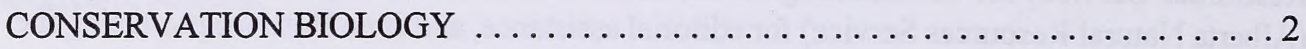

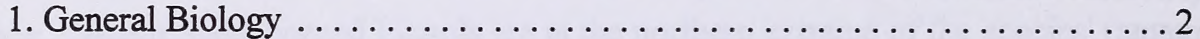

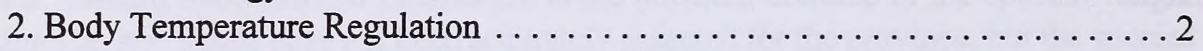

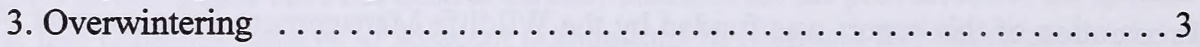

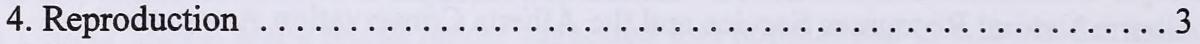

5. Home Range and Movement $\ldots \ldots \ldots \ldots \ldots \ldots \ldots \ldots \ldots \ldots \ldots \ldots$

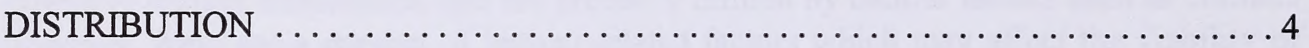

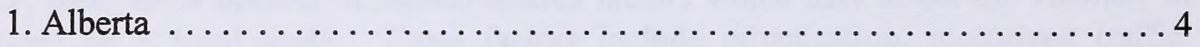

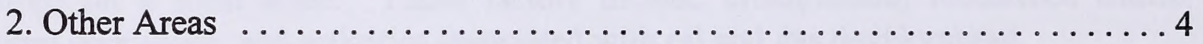

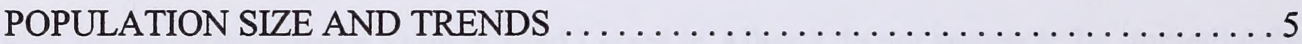

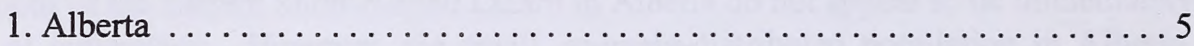

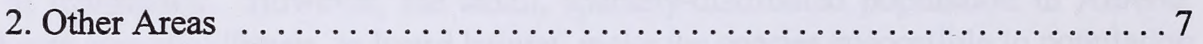

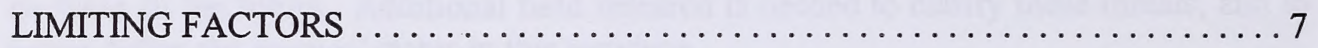

1. Agricultural Activities $\ldots \ldots \ldots \ldots \ldots \ldots \ldots \ldots \ldots \ldots \ldots \ldots \ldots$

2. Oil and Gas Exploration and Development ................ 9

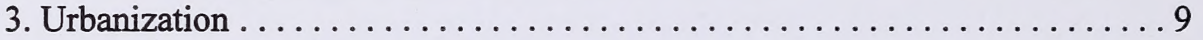

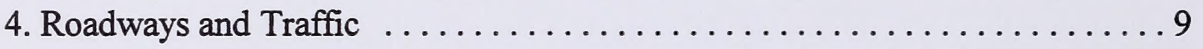

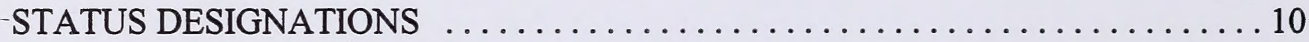

1. Alberta ....................................... 10

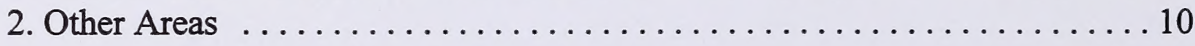

RECENT MANAGEMENT IN ALBERTA $\ldots \ldots \ldots \ldots \ldots \ldots \ldots \ldots \ldots \ldots \ldots \ldots$

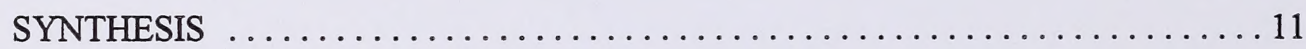

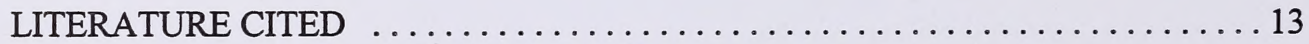

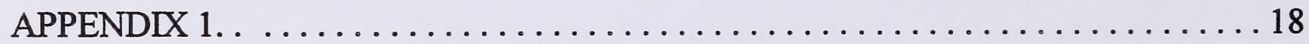

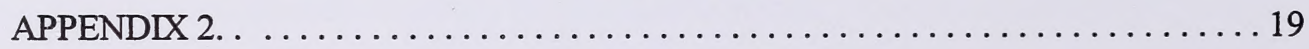




\section{INTRODUCTION}

Horned lizards (Phrynosoma spp.) are small, well-camouflaged reptiles which are endemic to arid regions of western North America. The subspecies found in Alberta is the Eastern Short-horned Lizard (P. douglassii brevirostre) which, at the northern extreme of its distribution, ranges into the southeastern corner of the province (Russell and Bauer 1993, Stebbins 1985). In the past, little was known about Eastern Short-horned Lizards in Alberta. Earlier status reviews had described the species as "threatened*" (Alberta Fish and Wildlife 1984) or had placed it on the provincial "Red List" (Alberta Fish and Wildlife 1991). The most recent provincial review of the status of Alberta wildlife has assigned the Eastern Short-horned Lizard to the "Blue List" of species which may be at risk in the province (Alberta Wildlife Management Division 1996).

Recent studies of the Eastern Short-horned Lizard in Alberta have resulted in the accumulation of a notable amount of information. The primary objective of this report is to provide a thorough summary of current knowledge of this species in Alberta as background for a review of the status of the species within the province.

\section{HABITAT}

The region occupied by Eastern Shorthorned Lizards in Alberta is one of the most climatically extreme on the Canadian prairies. Long, cold winters, the often very hot and dry summers, and the possibility of rapidly occurring, vast temperature fluctuations in any season are all climatic factors in this area (Anonymous 1993). The native vegetation over most of this region is generally mixed-grass prairie (Coupland 1961).

Short-horned Lizards in Alberta generally inhabit sparsely-vegetated, south-facing slopes of coulees and canyons, along the interface between the prairie grassland and the coulee bottom (Halladay 1965, Lewin 1963, Milner 1965, Powell 1982, Powell and Russell 1993a, Soper 1949, Wallis 1976, Williams 1946). McCorquedale (1965) also associated the species with the Bearpaw shale outcrops. Powell and Russell (1993a) distinguished three types of habitat within Alberta: the Milk River Basin habitat, Bearpaw habitat, and North Marginal habitat. In the Milk River Basin habitat type, lizards were found to occupy the ecotone between the short-grass prairie and the coulee and canyon margins (Powell and Russell 1993a). The Bearpaw, or "juniper-dunes" habitat type (along the southern perimeter of the Cypress Hills plateau) is comprised of sandy dunes, formed from Bearpaw shale, and is commonly matted with Creeping Juniper (Juniperus horizontalis). The North Marginal habitat is so described because these most northerly of known populations, seemingly restricted to the north rims of canyon and coulees with southern exposures, are thought to be less commonly occurring than populations further south (Powell and Russell 1993a).

Thinly-vegetated areas with southern aspects appear to be the most commonlyinhabited areas (Powell 1982, Powell and Russell 1985a), although lizards have been

*See Appendix 1 for definitions of selected status designations. 
found on east, west and some north-facing slopes as well (J. James, pers. obs.). The low profile and short legs of this species seems to render travel through thick vegetation more difficult. However, adult female lizards appear to readily use vegetation as a source of shade and overnight cover (J. James, pers. obs.). The lizards seem to require fine, friable soil which they can burrow into for overwintering.

In Alberta, Eastern Short-horned Lizards occupy habitat types which are limited in occurrence. However, the amount of available habitat in this province appears to be relatively stable, although it is subject to disturbance or destruction in some areas (see "Limiting Factors", below).

\section{CONSERVATION BIOLOGY}

1. General Biology. - As lizards go, horned lizards are very atypical. Rather than running, or seeking refuge in burrows from predators, horned lizards generally refrain from movement, even when approached. Camouflage is the primary means of predator evasion in horned lizards, and their mottled, sandy colouration and spiny skin blends in very well with the dry substrates they inhabit.

Phrynosomes are sit-and wait predators, dashing out and nabbing their prey as it wanders within range (Pianka 1966). Most phrynosomes consume primarily ants, and have specialized teeth and a large stomach capacity for the digestion of this highly chitinous food item (Pianka and Parker 1975). Horned lizards are round and flat in body shape, with sharp, spiked skin and short legs (Pianka and
Parker 1975). This aberrant lizard body form renders them rather slow and cumbersome in movement, which likely helped gain them the moniker "horned toad".

Eastern Short-horned Lizards in Alberta are relatively small creatures, with the average adult female weighing about $18 \mathrm{~g}$ (Powell and Russell 1985a, 1993a) and having an average snout-vent length (SVL) of approximately $70 \mathrm{~mm}$. Adult males are considerably smaller, with an average SVL of around $50 \mathrm{~mm}$ and weight of approximately $10 \mathrm{~g}$ (Powell and Russell 1993a). Short-horned Lizards in Alberta are generally active from emergence in mid- to late April or early May until around mid-September (Laird and Leech 1980, Powell and Russell 1991b, 1992a, 1993a, J. James, pers. obs.). However, observations of emergence as early as 1 April have been documented, with activity being sustained, although much reduced, until late October or early November (Powell and Russell 1993b, 1994, J. James, pers. obs.). Female Short-horned Lizards in Alberta are thought to live approximately five years, but the lifespan of males remains unclear (Powell and Russell 1985b, 1991a).

\section{Body Temperature Regulation. -} Horned lizards move between heat sources and heat sinks to control their internal body temperature within a preferred range, a characteristic behaviour among lizards known as shuttling (Heath 1964, 1965, Powell and Russell 1985a). These lizards often bask in direct sunlight (heliothermy) in order to increase body temperature. They may flatten the body (by extending the ribs), adjust their position, orientation, and tilt to increase surface area exposed to 
incident radiation (Heath 1964, 1965). Thigmothermy, or the gaining of heat from an object (such as a rock) has also been observed in these lizards (Heath 1965, J. James, pers. obs.). To cool, individuals may seek shade, alter their orientation, narrow the body profile, and may even burrow into the substrate (Heath 1964, 1965).

Prieto and Whitford (1971) found that Short-horned Lizards were capable of withstanding a greater temperature range, and had more variable body temperatures, than a co-occurring species of horned lizard. In Alberta, Eastern Short-horned Lizards have been found to tolerate a broad range of body temperatures (Powell and Russell 1985a, J. James, pers. obs.), and likely possess the ability to withstand freezing, which is probably vital to their survival in such a harsh environment (Powell and Russell 1994, 1996c). The median body temperature maintained by lizards in Alberta during the active part of the day is $32.9^{\circ} \mathrm{C}$ (Powell and Russell 1985a).

Adult female phrynosomes in Alberta have been noted to bask in direct sunlight in the morning, to maintain body temperature by shuttling and shifting orientation or position (often in a mosaic of sun and shade under vegetation) during mid-day, and to retreat under vegetative cover at dusk (J. James, pers. obs.). Lizards studied near Bow Island in southern Alberta generally remained under cover overnight (J. James, unpubl. data).

3. Overwintering. - The overwintering dens of Eastern Short-horned Lizards were initially hypothesized to be within the deep crevasses of the rock comprising the
Bearpaw formation which underlies much of the habitat of these lizards in Alberta (Powell and Russell 1992a, 1992b). However, radiotelemetry has shown that individuals simply excavate a relatively shallow burrow (approximately $10 \mathrm{~cm}$ beneath the surface) in the loose soil of a south-facing slope, perhaps relying on snow cover for insulation (Powell and Russell 1994, 1996b, J. James, pers. obs.). Overwintering mortality and mortality due to early and late seasonal extremes have been suggested as possible reasons for the low population densities of these lizards in Alberta (Powell and Russell 1994, 1996b).

4. Reproduction. - Short-horned Lizards are viviparous; they bear live young which have been carried to term internally (Blackburn 1982). Populations in Alberta exhibit marked sexual dimorphism, with adult females growing much larger than males (Powell and Russell 1985b). Mating in an Alberta population was observed to occur in mid- to late May (J. James, unpubl. data). Females reproduce annually, producing one clutch of young per year (Powell and Russell 1991a). Males may become sexually mature in their first year; females breed in their second year (Powell and Russell 1985b) bearing between six and 13 neonates of an even sex ratio (Powell and Russell 1991a). In Alberta, all females undergo parturition within a short time period near the end of July (Powell and Russell 1991a). Neonate survivorship is considered to be low; offspring weigh around $0.7 \mathrm{~g}$ at birth and are approximately $24 \mathrm{~mm}$ SVL (Pianka and Parker 1975, Powell and Russell 1991a). The reproductive effort appears to take a great physiological toll on females, and they appear gaunt and weak following 
parturition (Powell and Russell 1991a, J. James, pers. obs.).

\section{Home Range and Movement. -} Phrynosomes in Alberta which were monitored via radiotelemetry for periods of from one to three months, were recorded to have home ranges varying from 4.4 to $2400 \mathrm{~m}^{2}$ (Powell and Russell 1993b, 1994). Recent evidence (1994 1995) suggests that although temporary home ranges can be relatively small, the total home range areas used by Shorthorned Lizards in Alberta may be larger than previously established (Powell and Russell 1993b, 1994, 1996b, J. James, unpubl. data). Some female Short-horned Lizards were recorded to move significant distances prior to mating (more than 100 $\mathrm{m}$ over a one-week period), following parturition (usually $<50 \mathrm{~m}$ ), and again prior to hibernation (as far as $266 \mathrm{~m}$ over one week; J. James, unpubl. data). The distances recorded over these study seasons provided new insight into the movement capabilities of phrynosomes in Alberta.

\section{DISTRIBUTION}

\section{Alberta. - The Eastern Short-horned} Lizard is the most northerly occurring of all horned lizards (Russell and Bauer 1993, Stebbins 1985) with the northernmost limits of its distribution ranging into southeastern Alberta (Russell and Bauer 1993). In Alberta, Eastern Short-horned Lizards are found only in the southeastern corner of the province, with populations apparently located in disjunct zones along the Milk and South Saskatchewan Rivers and around the Chin Coulee, 40-Mile Coulee, and Pakowki Lake drainages (see Figure 1; Russell and Bauer 1993, Powell and Russell 1991b, 1993a). The seemingly clumped distribution may in part be a reflection of the limited records for this species over much of the potential range (Powell and Russell 1991b). Assessing the presence of the species, even in areas of confirmed captures, is often difficult due to the low population densities and cryptic habits of these lizards.

2. Other Areas. - Horned lizards are endemic to arid and semi-arid regions of west-central North America. There are thirteen species of horned lizards (Montanucci 1987) which are distributed from the northwestern corner of Guatemala to southern Canada (Pianka and Parker 1975, Reeve 1952, Stebbins 1985). Shorthorned Lizards (Phrynosoma douglassii) have the broadest range of all horned lizards in geographic, latitudinal and altitudinal terms (Heath 1965, Montanucci 1981, Reeve 1952, Russell and Bauer 1993, Smith 1946). There are five subspecies of Short-horned Lizards which are found to inhabit mountainous areas, plains, and arid uplands within their distribution. These subspecies range from Chihuahua and Durango in Mexico, to the southernmost regions of the western Canadian provinces (see Figure 2; Montanucci 1981, Reeve 1952, Russell and Bauer 1993, Sherbrooke 1981, Smith 1946).

Two Pygmy Short-horned Lizards ( $\underline{\mathrm{P}}$. $\underline{\mathrm{d}}$. douglassii) were collected in the Osoyoos region of British Columbia by Fannin (1898). However, attempts to locate a contemporary population were unsuccessful and the species is presumed to be extirpated in that province (Powell and Russell 1991c). In Saskatchewan, Eastern Short-horned Lizards have been recorded in the extreme south-central portion of the 


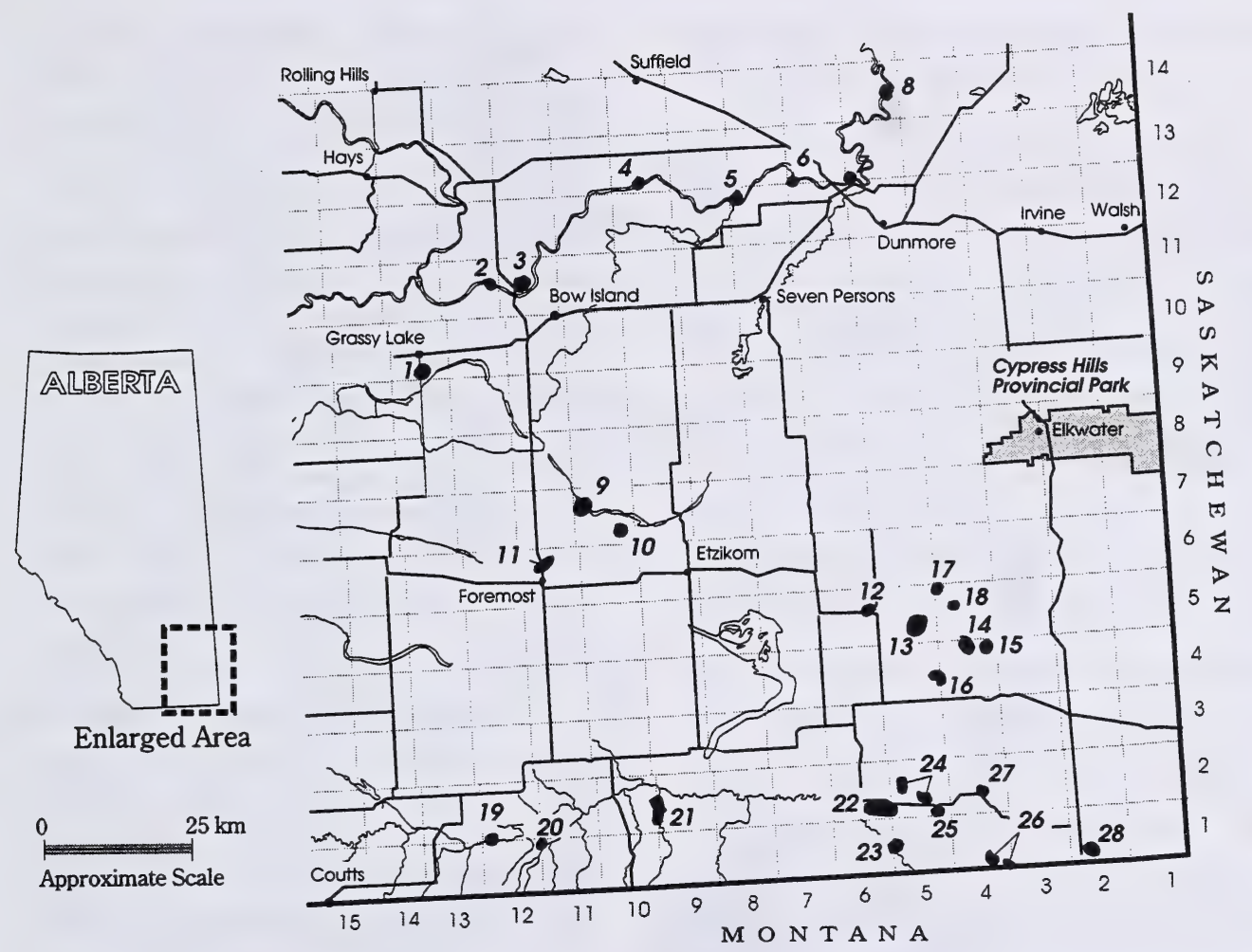

Figure 1. Distribution of the Eastern Short-horned Lizard in Alberta. Numbered sites are described in Appendix 2.

province, primarily along the drainages of the Frenchman and Poplar Rivers (Powell and Russell. 1993a, 1996c). A recent survey of Grasslands National Park found the species in juniper-dune habitat in the West Block, along the Frenchman River valley, and limited to within $30 \mathrm{~km}$ of the border (Powell et al. in prep.). The East Block population, which was located on more vegetated slopes above alkaline alluvial flats, was found to be relatively limited in size and is suspected to be marginal in range (Powell et al. in prep.).

\section{POPULATION SIZE AND TRENDS}

1. Alberta. - In the absence of any detailed studies of long-term population trends of Eastern Short-horned Lizards in Alberta, any supposed changes in population are subjective extrapolations from field work done by the only individual (G. L. Powell, University of Calgary) to have studied these lizards over a considerable period of time. The incidental observations of local residents have also provided an indication of the relative abundance of phrynosomes in some areas (Powell and Russell 1993a). 


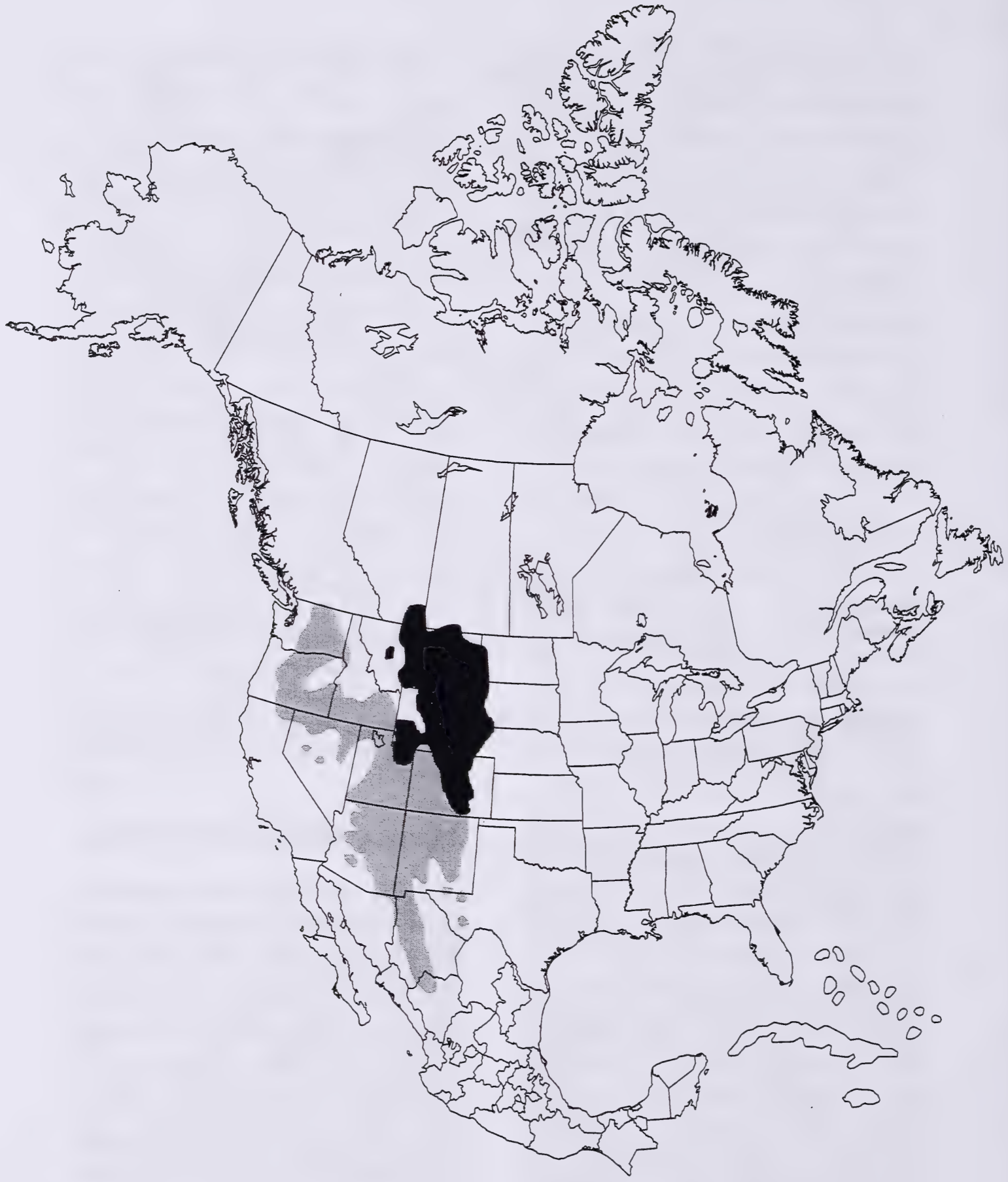

Figure 2. Range of Short-horned Lizards (Phrynosoma douglassii) in North America (after Conant 1975, and Stebbins 1985). The dark area depicts the range of the Eastern Short-horned Lizard subspecies (․․ d. brevirostre). 
Population densities of Eastern Shorthorned Lizards in Alberta have been described as low (Powell 1982, Powell and Russell 1985b, 1991b, 1992a,b, 1993a,b, 1994). In other regions, the population density has also been described as low (Pianka and Parker 1975), but it is suspected that the densities of lizards in Canada are notably less than those in areas further south (Powell and Russell 1996c). For example, in most areas where phrynosomes are found in Alberta, a good field day is one in which only two to four lizards may be captured over the course of an eight-hour search in prospective habitat. In contrast, the capture rate for Shorthorned Lizards in northern California is considerably higher, and perhaps 20 or more may be encountered per day (K. Zamudio, pers. comm.).

Powell and Russell (1992a) suggested that the overall population of Eastern Shorthorned Lizards in Alberta appeared to have declined between the time of the early field work done by Powell (1978 - 1982) and field work done in 1991. The conclusions were tentative as a result of poor weather in the field, limited manpower, and the limited number of populations for which relatively comparative information was available from previous years. Nevertheless, field searches in 1991 yielded much lower capture rates than were documented 11 years earlier. The authors proposed that the prolonged drought over much of that period may have been responsible for the apparent decline in population size. Reduced insect populations resulting from the general depression of productivity during drought could have acted to decrease fecundity in Short-horned Lizards, resulting in a cumulative population decline over the region (Powell and Russell 1992a).

There is a dramatic annual increase in the population of these lizards immediately following parturition in late July (Powell and Russell 1985b). It is during this time period that the highest density of neonates occurs, and the relative inexperience of newborns causes them to be more easily frightened into movement and be found by researchers. As such, the most effective time of year in which to search for the presence of Eastern Short-horned Lizards in Alberta is the early part of August.

2. Other Areas. - Little is known of the population size of Eastern Short-horned Lizards in Saskatchewan, and although recent investigations have provided improved baseline information, no confident comments regarding population size or trends can be made (Powell et al. in prep.). The population of Pygmy Shorthorned Lizards in British Columbia is considered to be extirpated, with no specimens having been collected since 1898 (Fannin 1898, Powell and Russell 1991c). The Eastern Short-horned Lizard in Montana is described as "...widely distributed (but somewhat localized) in eastern Montana" (Reichel and Flath 1995). The species is currently considered to be "locally common" in that state (D. Flath, pers. comm.).

\section{LIMITING FACTORS}

Lizard populations in Alberta may be impacted by both natural and humanrelated influences. The first potentially limiting natural factor for Eastern Shorthorned Lizards in Alberta is climate. Phrynosomes in Canada are at the 
northernmost limit of their range (Russell and Bauer 1993, Stebbins 1985). As such, climatic constraints may play an important role in the distribution of these lizards in the province (Powell and Russell 1991a). Predation may also be a natural factor limiting the size of lizard populations in Alberta. However, losses to predation are presumed to be minimal, because the small size, low density, and cryptic habitats of these lizards would not likely make them the primary prey choice for many predators (Powell and Russell 1996c).

The focus of the remainder of this section is on human-related impacts on Eastern Short-horned Lizards in the province. In Alberta, the species tends to occupy areas which are not agriculturally productive, nor commonly visited by many people. Powell and Russell (1993a) listed grazing, cultivation, oil and gas exploration, and urbanization as potentially limiting human impacts for the Eastern Short-horned Lizard in Canada. They noted that these factors vary in importance within the range of the lizard in Canada, and that more is known about the effects of these activities in Alberta than in Saskatchewan.

\section{Agricultural Activities. - Grazing is the} most common human-initiated land use over most of the area in which lizards are found in Alberta. According to Powell and Russell (1993a), cattle grazing is unlikely to have much potential influence on Shorthorned Lizard populations, and is probably comparable to the impact of Bison (Bison bison) in the past. In fact, Reynolds (1979) found that Pygmy Short-horned Lizards in Idaho apparently responded positively to the reduced vegetative cover caused by grazing.
Powell and Russell (1993a) note that the only aspects of cattle grazing likely to have deleterious effects are physical damage near coulee edges, and the seeding of invasive species such as crested wheatgrass (Agropyron cristatum) which may restrict the movements of Short-horned Lizards. These lizards tend to inhabit areas which cattle do not prefer (steep hillsides, juniper dunes), and other livestock-related activities are generally limited in scope or occur away from the habitat occupied by the lizards. Therefore, the overall impact of cattle grazing on Short-horned Lizard populations in Alberta is thought to be relatively minimal (Powell and Russell 1993a).

Cultivation and related activities are listed by Powell and Russell (1993a) as the second most common human activity over the range of Eastern Short-horned Lizards in Alberta. Once again, lizards inhabit areas which are not likely subjected to cultivation, but the extent of use of such "marginal" land is dependent upon individual landowners (Powell and Russell 1993a). Cultivation close to coulee edges could eliminate habitat (Powell and Russell 1993a), but Powell and Russell (1993a) concluded that, in general, agriculture was not a significant limiting factor for these lizards in Alberta. One exception, which may have contributed to the extinction of at least one population, involved the creation of an irrigation reservoir and the consequent flooding of the surrounding hillsides which were previously inhabited by phrynosomes (Powell and Russell 1992, Powell and Russell 1993a).

Another aspect of the effects of modern agriculture on Short-horned Lizards in Alberta which was only briefly discussed 
by Powell and Russell (1993a) is the potential impact of insecticides. These lizards consume ants, grasshoppers, crickets and beetles (Powell and Russell 1984). Agricultural pesticides, although not commonly used on an annual basis over the region, may be used heavily in some years to control insects (primarily grasshoppers) when populations increase to destructive levels, especially in areas near croplands. The possibility exists that these chemicals may be used even in some of the more marginal agricultural areas which are inhabited by phrynosomes. The probability of direct ingestion of poisoned prey would increase greatly under such circumstances.

\section{Oil and Gas Exploration and} Development. - The oil and gas industry is active within much of the range of the Eastern Short-horned Lizard in Alberta, particularly in the Manyberries area (Powell and Russell 1991b, 1992a,b, 1993a, 1996b, Smith 1993). Powell and Russell (1993a) noted that although the installation of pipelines was likely to cause some disturbance for Short-horned Lizard populations, there appeared to be no great lasting influence. Exploration and development, however, may have more major impacts (Powell and Russell 1993a, Smith 1993).

Powell and Russell (1993a) noted that the tracks left by vehicles have been observed to be used by Short-horned Lizards as travel routes through grassy areas, exposing them to being run over by other vehicles following the same track. At least one phrynosome has been recorded to have been run over on an oil access roadway (G. L. Powell, pers. obs.). The tracks themselves also promote the access of other vehicles, by providing an enticing avenue for adventurous drivers.

The creation of large cleared areas for the setup of drilling rigs in areas occupied by lizards reduces, or if not properly reclaimed with native grasses, destroys, part of the limited amount of available habitat. Erosion by wind and water may cause further harm to disrupted areas of habitat (Powell and Russell 1993a). The juniper dunes habitat type is particularly vulnerable to such damage, and has been subjected to a notable amount of disturbance from oil and gas exploration in the Manyberries area (Powell and Russell 1991b, 1992a,b, 1993a, 1996b, Smith 1993).

3. Urbanization. - Urbanization does not directly affect a large amount of Shorthorned Lizard habitat in Alberta. The few populations that have been impacted are primarily those near and within the city of Medicine Hat. In this area, urbanization may affect Short-horned Lizard populations directly, through the loss or fragmentation of habitat, predation by domestic predators, and collection by inquisitive children or adults, or indirectly, by the danger of being run over by traffic of various sorts (Powell and Russell 1993a). The extent of the effect of urbanization remains unknown because of the paucity of information regarding exact locations of populations prior to growth of the city (Powell and Russell 1993a).

4. Roadways and Traffic. - There may be important local ramifications for Shorthorned Lizard populations caused by roads or roadways or the use of motorized vehicles such as dirt bikes, all-terrain vehicles, and even truck traffic over the home range areas of the animals. Some 
female phrynosomes were recently documented to move considerable distances over relatively short periods of time (J. James, unpubl. data). As such, there exists the possibility that these animals may be more vulnerable to roadkill than previously thought if they attempt to migrate across roads to otherwise undivided habitat areas. There is also a possibility that trucks and other vehicles used by ranchers and the general public within the range of these animals present a danger to the lizards, as their small size and habit of remaining motionless until approached likely reduces their response time to avoid oncoming vehicles.

The use of recreational vehicles in the coulees and river valleys that the lizards occupy is also a potential threat to some phrynosomes. The extensive use of dirt bikes on some hillsides causes extreme damage to vegetation and soil stability over a considerable area, and enhances the possibility of direct mortality to lizards (J. James, pers. obs.). All-terrain vehicles, as well as truck traffic, are also commonly used in the field areas near or within Shorthorned Lizard ranges, and may also present a danger to these lizards. One incident of a Short-horned Lizard being run over and killed by an all-terrain vehicle has been noted (anecdotal report by M. Laidlaw, July 1996). As the lizards are very small and cryptic, the likelihood of them being noticed by drivers, even after having been run over, is extremely low.

\section{STATUS DESIGNATIONS}

1. Alberta. - A review of the status of fish and wildlife resources in 1984 described the Eastern Short-horned Lizard in Alberta as being "threatened" (Alberta Fish and
Wildlife 1984). In 1985, a provincial government report placed the Eastern Short-horned Lizard on the list of species considered to be peripheral to the province (Alberta Fish and Wildlife 1985). In 1991, the species was described as being "rare and localized", and was included on the "Red List" as a species considered to be at immediate risk of declining to nonviable levels (Alberta Fish and Wildlife 1991). The "Background" section of that report commented that "Population status and trend [is] unknown, but [this species] occurs in strongly localized and isolated sandy grassland/badland/river break habitats" (Alberta Fish and Wildlife 1991). Most recently, the Eastern Short-horned Lizard has been moved to the provincial "Blue List" of species which may be at risk in the province (Alberta Wildlife Management Division 1996).

The Eastern Short-horned Lizard is legally designated as a "non-game animal" under the Alberta Wildlife Act. Animals included in this designation are provided with full protection, and may not be killed, possessed, bought or sold without a permit.

2. Other Areas. - In Saskatchewan, Eastern Short-horned Lizards have not been granted official status, although they have been described as "rare" (Secoy 1987) and, under the Wildlife Act, may not be collected in that province without a license (Anonymous 1996). In British Columbia, the Pygmy Short-horned Lizard has been classified as "extirpated" (Powell and Russell 1991c, 1992b). In the state of Montana, where the nearest adjoining populations of these animals are found, there has been no official status accorded the species (D. Flath, pers. comm.). Phrynosoma douglassii is classified as 
"threatened" in Texas, primarily to protect it from collectors (W. Hodges, pers. comm.). The species is not legally protected in Arizona or Nevada, and is in fact commercially collectable in the latter state (W. Hodges, pers. comm.).

The Eastern Short-horned Lizard is listed as "vulnerable" in Canada by the Committee On the Status of Endangered Wildlife In Canada (COSEWIC; Anonymous 1994, Powell and Russell 1992b). This status was assigned because current populations are small and possibly declining, and because of the restricted distribution of suitable habitat.

\section{RECENT MANAGEMENT IN ALBERTA}

No direct management of Eastern Shorthorned Lizard populations or habitat has been undertaken in Alberta. However, there have been several research studies which have investigated many aspects of the biology, range, and the ecology of the species in this province. These studies (Powell 1982, Powell and Russell 1984, 1985a,b, 1991a,b, 1992a,b, 1993a,b, 1994, 1996a,b, Smith 1993) have served to greatly increase the understanding of this species in Alberta, and may in turn contribute to the direction of any management in the future.

To study population trends of the ShortHorned Lizard in Alberta, Powell and Russell (1992a, 1993a) examined the status of populations over the known range in Alberta. Smith (1993) investigated the habitat and status of the populations in one area of the range subject to substantial oil and gas development, the Manyberries badlands. Next, a three-year study of the home range size and overwintering strategy in the Manyberries Creek valley was undertaken using radiotelemetry (Powell and Russell 1992a 1993a). Important data on habitat use and yearly activity patterns were obtained (Powell and Russell 1993b, 1994), and new suggestions were made concerning the suspected cause of the limited range of the species in Alberta, updating previous theories (Powell and Russell 1985a, 1991a,b 1993a, 1996b). Over the field seasons of 1994-1995, J. James used thermally-sensitive radiotelemetry to investigate the thermal patterns of gravid and non-gravid female Short-horned Lizards, over their entire active season. The study was undertaken at one of the most northerly of known population sites, along the South Saskatchewan River northwest of the town of Bow Island. As well as determining the thermal patterns exhibited by reproductive females, a notable amount of additional information regarding hibernation, courtship behaviour, movement patterns and predation was gleaned (J. James, unpubl. data).

The greater awareness of the species in recent years has led to at least one example of active habitat reclamation efforts by industrial interests. As noted previously, a significant amount of oil and gas development occurs within the range of the Eastern Short-horned Lizard in Alberta (Powell and Russell 1991b, 1992a,b, 1993a, 1996b, Smith 1993). Samedan Oil of Canada, after purchasing the rights to drill in an area of southeastern Alberta, found lizards on the proposed drilling site (New 1991). Several provisions were made to reduce the impact of the exploration, and efforts were made to reclaim the habitat disturbed by the project 
(Hornbeck and Green 1990, 1991, New 1991).

\section{SYNTHESIS}

In Alberta, the Eastern Short-horned Lizard is at the northern edge of the species' range, and occurs in a limited number of areas in the extreme southeastern part of the province. Populations are at relatively low densities, and are probably limited by natural factors such as climate, and humanrelated factors such as agricultural practices, oil and gas development, urbanization and road construction, and off-road recreational traffic.

The limited distribution, small population size, and potential threats to existing habitat make the Eastern Short-horned Lizard susceptible to population declines in Alberta. In fact, there is limited evidence to suggest that such declines have occurred over the past fifteen years. However, repeated surveys, over a number of years at fixed localities will be required to confirm this suspected trend. Such surveys, if supplemented by research techniques (e.g., telemetry and marking), would also allow the collection of more detailed information on the biology of this species, including average lifespan and survivorship, fecundity, movements, habitat selection, and genetic relatedness of populations. Such information would serve to clarify the population status and potential threats to the Eastern Short-horned Lizard in Alberta. 


\section{LITERATURE CITED}

Alberta Fish and Wildlife. 1984. Status of the fish and wildlife resource in Alberta. Alberta Fish and Wildlife, Edmonton, AB. 123 pp.

Alberta Fish and Wildlife. 1985. A policy for the management of threatened wildlife in Alberta. Alberta Fish and Wildlife, Edmonton, AB. 34 pp.

Alberta Fish and Wildlife. 1991. The status of Alberta wildlife. Alberta Fish and Wildlife, Edmonton, AB. 49 pp.

Alberta Wildlife Management Division. 1996. The status of Alberta wildlife. Alberta Natural Resources Service, Edmonton, AB. 44 pp.

Anonymous. 1993. Canadian climate normals, 1961-1990. Prairie provinces. Environment Canada, Atmospheric Service, Canadian Climate Program. Catalogue No. En56-61/2-1993.

Anonymous. 1994. Endangered species in Canada (and other wildlife at risk). List of species at risk in Canada as determined by the Committee on the Status of Endangered Wildlife in Canada (COSEWIC). World Wildlife Fund Canada, Toronto, ON.

Anonymous. 1996. Saskatchewan Wildlife Act. W-13.1 Reg. 1. Part II. General Hunting Restrictions.

Bartholomew, G. A. 1982. Physiological control of body temperature. Pp. 165211 in Biology of the Reptilia, vol. XII (C. Gans and F. H. Pough, eds.). Academic Press, London, UK. 536 pp.
Blackburn, D. G. 1982. Evolutionary origins of viviparity in the Reptilia. I. Sauria. Amphib. Reptilia 3: 185-205.

Conant, R. 1975. A field guide to reptiles and amphibians of eastern and central North America, 2nd edn. HoughtonMifflin Co., Boston, MA. 429 pp.

COSEWIC. 1996. Canadian species at risk. Committee on the Status of Endangered Wildlife in Canada, Ottawa, ON. $18 \mathrm{pp}$.

Coupland, R. T. 1961. A reconsideration of grassland classification in the northern Great Plains of North America. J. Ecol. 49: 135-167.

Fannin, J. 1898. Reptilia of British Columbia. A preliminary catalogue of the collections of natural history and ethnology in the Provincial Museum. pp. 57-58.

Halladay, I. R. 1965. Recent biota of the Cypress Hills Plateau. A general survey of the natural history. Pp. 37-54 in Alberta Society of Petroleum Geologists 13th Annual Field Conference Guide, Part 1 (R. L. Zell, ed.).

Heath, J. E. 1964. Head-body temperature differences in horned lizards. Physiol. Zool. 37: 273.

Heath, J. E. 1965. Temperature regulation and diurnal activity in horned lizards. University of California Press, Berkeley and Los Angeles, CA. 135 pp.

Hornbeck, G. E., and J. E. Green. 1990. A reconnaissance field survey of the Eastern Short-horned Lizard and its 
habitat in Samedan Manyberries 9-13-45 W4M. Delta Environmental Management Group Ltd. Calgary, AB. $27 \mathrm{pp}$.

Hornbeck, G. E., and J. E. Green. 1991. Year two (1991) of a reconnaissance field survey of the Eastern Short-horned Lizard and its habitat in Samedan Manyberries 9-13-4-5 W4M. Delta Environmental Management Group Ltd. Calgary, AB. 17 pp.

Laird, M., and R. Leech. 1980. Observations of the Short-horned Lizard in southeastern Alberta. Blue Jay. 39: 214-218.

Lewin, V. 1963. The herptofauna of southeastern Alberta. Can. Field-Natur. 77: 203-214.

Logier, E. B. S., and G. C. Toner. 1961. Checklist of the amphibians and reptiles of Canada and Alaska, 2nd edn. Contributions No. 53, Life Sciences Division, Royal Ontario Museum, Toronto, ON. 92 pp.

McCorquedale, B. 1965. Some peculiar aspects of the biota of the Cypress Hills. Pp. 55-65 in Alberta Society of Petroleum Geologists 13th Annual Field Conference Guide, Part 1 (R. L. Zell, ed.).

Milner, B. J. 1979. Northern Short-horned Lizard in southeastern Alberta. Alberta Natur. 9: 90-92.

Montanucci, R. R. 1981. Habitat separation between Phyrnosoma douglassii and $\underline{\mathrm{P}}$ orbicular (Lacertila:
Iguanidae) in Mexico. Copeia 1981: 147-153.

Montanucci, R. R. 1987. A phylogenetic study of the horned lizards, genus Phrynosoma, based on skeletal and external morphology. Nat. Hist. Mus. Los Angeles Contrib. Sci. No. 390: 136.

Montanucci, R. R., and B. E. Bauer. 1982. Mating and courtship-related behaviors in the Short-horned Lizard, Phrynosoma douglassii. Copeia 1982: 971-974.

National Research Council. 1995. Science and the Endangered Species Act. National Academy Press, Washington, DC. $271 \mathrm{pp}$.

New, E. R. 1991. Drilling in Short-horned Lizard country. Abstract presented at the CADE/CAODC Spring Drilling Conference, April 10-12, 1991. CADE/CAODC Conference Publications. Calgary, $A B$.

Pianka, E. R. 1966. Convexity, desert lizards and spatial heterogeneity. Ecology 47: 1055-1059.

Pianka, E. R., and W. S. Parker. 1975. Ecology of horned lizards: a review with special reference to Phrynosoma platyrhinos. Copeia 1975:141-162.

Powell, G. L. 1982. The Eastern Shorthorned Lizard in Alberta: Basic field ecology of northern marginal populations. Unpubl. M.Sc. thesis, University of Calgary, Calgary, AB. $343 \mathrm{pp}$. 
Powell, G. L. and A. P. Russell. 1984. The diet of the Eastern Short-horned Lizard (Phrynosoma douglassii brevirostre) in Alberta and its relationship to sexual size dimorphism. Can. J. Zool. 62: 428-440.

Powell, G. L., and A. P. Russell. 1985a. Field thermal ecology of the Eastern Short-horned Lizard (Phrynosoma douglassii brevirostre) in southeastern Alberta. Can. J. Zool. 63: 228-238.

Powell, G. L., and A. P. Russell. 1985b. Growth and sexual size dimorphism in Alberta populations of the Eastern shorthorned lizard, Phrynosoma douglassii brevirostre. Can. J. Zool. 63: 139-154.

Powell, G. L., and A. P. Russell. 1991a. Parturition and clutch size characteristics of short-horned lizards (Phrynosoma douglassii brevirostre) from Alberta. Can. J. Zool. 69: 27592764.

Powell, G. L., and A. P. Russell. 1991 b. Distribution of the Eastern short-horned lizard (Phrynosoma douglassii brevirostre) in Alberta, Canada. Northwest. Natur. 72: 21-26.

Powell, G. L., and A. P. Russell. 1991c. Report on the 1991 search for the Pygmy Short-horned Lizard (Phrynosoma douglassii douglassii) in the region of Osoyoos, British Columbia. The Wildlife Branch, B.C. Environment, Victoria, BC. 27 pp.

Powell, G. L., and A. P. Russell. 1992a. A preliminary survey of the distribution and abundance of the Eastern Shorthorned Lizard (Phrynosoma douglassii brevirostre) in Alberta. Unpubl. rept. to The Recreation, Parks and Wildlife Foundation, Edmonton, AB. 135 pp.

Powell, G. L., and A. P. Russell. 1992 b. The status of the short-horned lizard (Phrynosoma douglassii) in Canada. Committee on the Status of Endangered Wildlife in Canada, Ottawa, ON. 22 pp.

Powell, G. L., and A. P. Russell. 1993a. The range and status of the Eastern Short-horned Lizard in the Canadian prairies. Pp. 278-290 in Proceedings of the 3rd prairie conservation and endangered species workshop (G. L. Holroyd, H. L. Dickson, M. Regnier and H.C. Smith, eds.). Prov. Mus. Alberta Nat. Hist. Paper No. 19, Edmonton, AB. 384 pp.

Powell, G. L., and A. P. Russell. 1993 b. A radio telemetric study of movement and thermal ecology in an Alberta population of the Eastern Short-horned Lizard (Phrynosoma douglassii brevirostre). Unpubl. report to Alberta Fish and Wildlife Division, Lethbridge, AB. 74 pp.

Powell, G. L., and A. P. Russell. 1994. A radio telemetric study of movement, thermal ecology and hibernation site selection in an Albertan population of the Eastern Short-horned Lizard (Phrynosoma douglassii brevirostre). Unpubl. report to Alberta Fish and Wildlife Division, Lethbridge, AB. 132 pp.

Powell, G. L., and A. P. Russell. 1996a. Alberta's amphibians and reptiles: current research and conservation issues. 
Pp. 253-255 in Proceedings of the fourth prairie conservation and endangered species workshop (W. D. Willms and J.F. Dormaar, eds.). Prov. Mus. Alberta Nat. Hist. Occas. Paper No. 23, Edmonton, AB. 337 pp.

Powell, G. L., and A. P. Russell. 1996 b. Movement, thermal ecology, seasonal activity, and overwintering behaviour in an Alberta population of the Eastern Short-horned Lizard (Phrynosoma douglassii brevirostre). Alberta Fish and Wildlife Division, Lethbridge, $\mathrm{AB}$. $128 \mathrm{pp}$.

Powell, G. L., and A. P. Russell. 1996c. Short-horned Lizards (Phrynosoma douglassii brevirostre) in Grasslands National Park: a report on the 1995 field season. Unpubl. rept., Parks Canada, Val Marie, SK. 74 pp.

Powell, G. L., A. P. Russell, and P. Fargey. In Prep. The distribution of the Eastern Short-horned Lizard in Saskatchewan, Canada.

Prieto, A. A., Jr., and W. G. Whitford. 1971. Physiological responses to temperature in the horned lizards Phrynosoma cornutum and Phrynosoma douglassii. Copeia 1971: 498-504.

Reeve, W. L. 1952. Taxonomy and distribution of the horned lizards genus Phrynosoma. Univ. Kans. Sci. Bull. 34:817-960.

Reichel, J. and D. Flath. 1995. Identification of Montana's amphibians and reptiles. Montana Outdoors, May/June, 1995.
Reynolds, W. L. 1979. Response of reptile populations to different land management practices on the Idaho National Engineering Laboratory Site. Great Basin Natur. 39: 255-262.

Roberts, W. E. 1982. Threatened or endangered native species of amphibians and reptiles of Alberta. Alberta Natur. 12: 54 .

Russell, A. P., and A. M. Bauer. 1993. The amphibians and reptiles of Alberta. University of Calgary and University of Alberta Presses, Calgary and Edmonton, AB. 264 pp.

Schowalter, D. B. 1979. New distribution records of the horned lizard in Alberta. Blue Jay 37: 26-27.

Secoy, D. M. 1987. Status report on the reptiles and amphibians of Saskatchewan. Pp. 139-141 in Endangered species in the prairie provinces (G. L. Holroyd, P. H. R. Stepney, G. C. Trottier, W. B. McGillivray, D. M. Ealey, and K. E. Eberhart, eds.). Prov. Mus. Alberta Nat. Hist. Occ. Paper No. 9, Edmonton, AB. $367 \mathrm{pp}$.

Sherbrooke, W. C. 1981. Horned lizards. Unique reptiles of western North America (E. Jackson, ed.). Southwest Parks and Monuments Association, Phoenix, AZ. 48 pp.

Smith, H. M. 1946. Handbook of lizards. Comstock Publishing, Ithaca, NY. $557 \mathrm{pp}$. 
Smith, W. W. 1975. Some southern Alberta animals - 1974. Blue Jay 33: 118-119.

Smith, W. 1993. An assessment of Shorthorned Lizard habitat and use, Manyberries badlands, Alberta. Unpubl. rept. to Alberta Fish and Wildlife, Lethbridge, AB. 63 pp.

Soper, J. D. 1949. Notes on the fauna of the former Nemiskam National Park and vicinity, Alberta. Can. Field- Natur. 63: 167-182.
Stebbins, R.C. 1985. A field guide to western reptiles and amphibians, 2nd edn. Houghton Mifflin Co., Boston, MA. $336 \mathrm{pp}$

Wallis, C. 1976. Milk River Canyon resource evaluation. Alberta Recreation, Parks and Wildlife, Edmonton, AB. 122 pp.

Williams, M. Y. 1946. Notes on the vertebrates of the southern plains of Canada, 1923-26. Can. Field-Natur. 60: 47-60. 


\section{A. Status of Alberta Wildlife color lists (after Alberta Wildlife Management Division 1996)}

\begin{tabular}{|l|l|}
\hline Red & $\begin{array}{l}\text { Current knowledge suggests that these species are at risk. These species have declined, or are } \\
\text { in immediate danger of declining, to nonviable population size }\end{array}$ \\
\hline Blue & $\begin{array}{l}\text { Current knowledge suggests that these species may be at risk. These species have undergone } \\
\text { non-cyclical declines in population or habitat, or reductions in provincial distribution }\end{array}$ \\
\hline Yellow & $\begin{array}{l}\text { Species that are not currently at risk, but may require special management to address concerns } \\
\text { related to naturally low populations, limited provincial distributions, or demographic/life } \\
\text { history features that make them vulnerable to human-related changes in the environment }\end{array}$ \\
\hline Green & Species not considered to be at risk. Populations are stable and key habitats are generally secure \\
\hline Undetermined & Species not known to be at risk, but insufficient information is available to determine status \\
\hline
\end{tabular}

\section{B. Alberta Wildlife Act}

Species designated as "endangered" under the Alberta Wildlife Act include those defined as "endangered" or "threatened" by $A$ Policy for the Management of Threatened Wildlife in Alberta (Alberta Fish and Wildlife 1985):

\begin{tabular}{|l|l|}
\hline Endangered & A species whose present existence in Alberta is in danger of extinction within the next decade \\
\hline Threatened & $\begin{array}{l}\text { A species that is likely to become endangered if the factors causing its vulnerability are not } \\
\text { reversed }\end{array}$ \\
\hline
\end{tabular}

\section{Committee on the Status of Endangered Wildlife in Canada (after COSEWIC 1996)}

\begin{tabular}{|l|l|}
\hline Extirpated & A species no longer existing in the wild in Canada, but occurring elsewhere \\
\hline Endangered & A species facing imminent extirpation or extinction \\
\hline Threatened & A species likely to become endangered if limiting factors are not reversed \\
\hline Vulnerable & $\begin{array}{l}\text { A species of special concern because of characteristics that make it particularly sensitive to } \\
\text { human activities or natural events }\end{array}$ \\
\hline Not at Risk & A species that has been evaluated and found to be not at risk \\
\hline Indeterminate & A species for which there is insufficient scientific information to support status designation \\
\hline
\end{tabular}

\section{United States Endangered Species Act (after National Research Council 1995)}

\begin{tabular}{|l|l|}
\hline Endangered & Any species which is in danger of extinction throughout all or a significant portion of its range \\
\hline Threatened & $\begin{array}{l}\text { Any species which is likely to become an endangered species within the foreseeable future } \\
\text { throughout all or a significant portion of its range }\end{array}$ \\
\hline
\end{tabular}




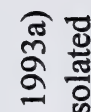

.

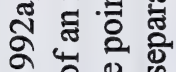

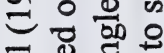

》

ชิ ๘

동ㅎㅀ응

잉요

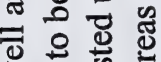

ปั

ค ㄹ. 때

ㄱㅡㄴㅀㅇ을

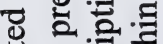

플 융

힝으 용

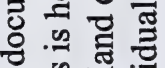

픈 을

․ㅗㅇ.

《词 등

퓨 흘

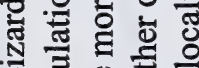

ప 응 원

¿

ㄱ.

닌 预.

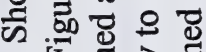

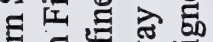

गु. 잉 ज

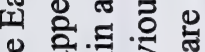

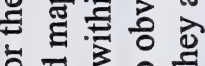

흘 을

भ ส

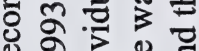

을 능

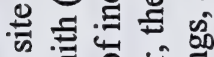

饮

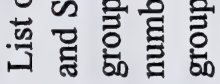

준

\begin{tabular}{|c|c|c|c|c|c|c|c|c|c|c|c|c|c|c|}
\hline है & 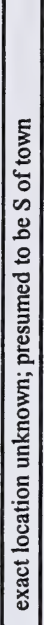 & 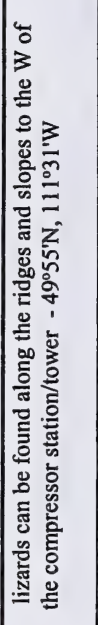 & 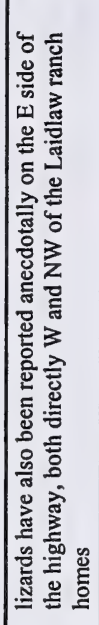 & 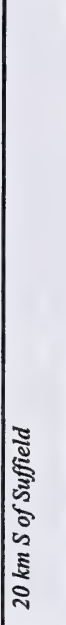 & & 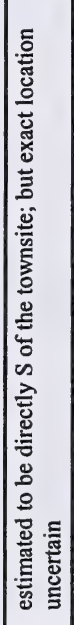 & 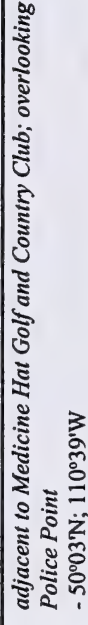 & 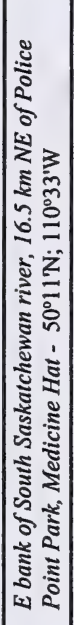 & 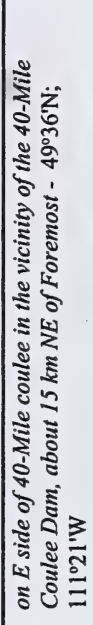 & 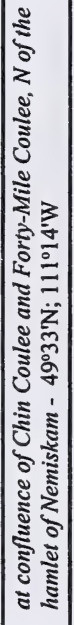 & 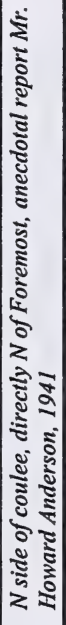 & 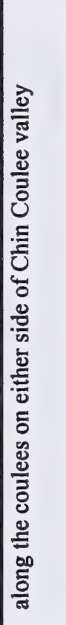 & 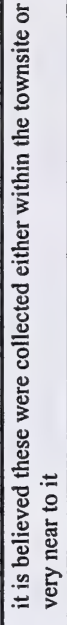 & 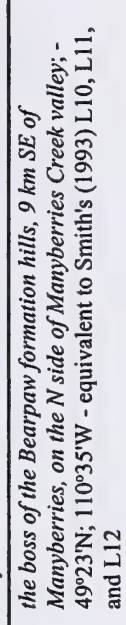 \\
\hline हूँ & 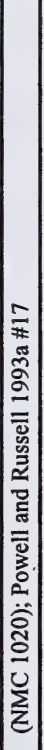 & 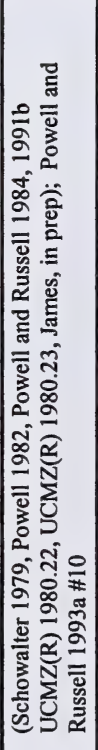 & 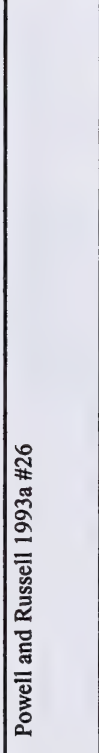 & 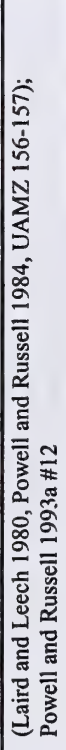 & 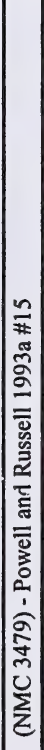 & 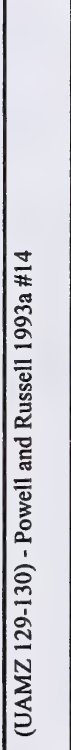 & 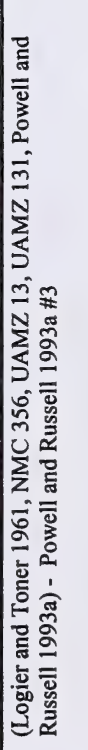 & 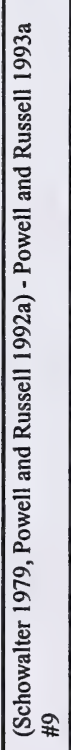 & 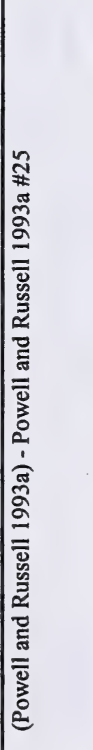 & 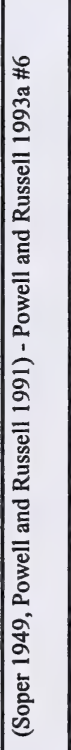 & 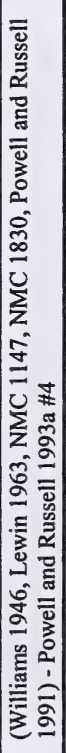 & 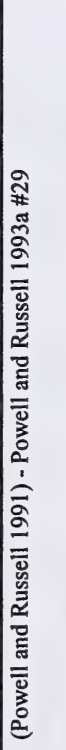 & 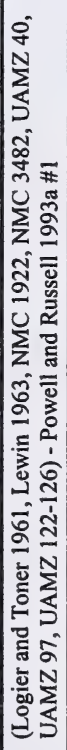 & 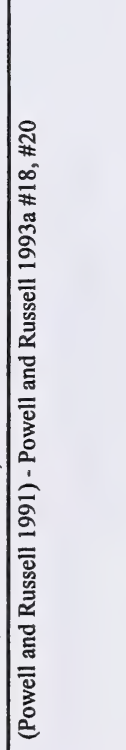 \\
\hline 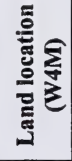 & 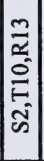 & 胥 & 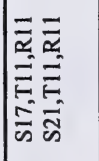 & $\begin{array}{l}\frac{2}{2} \\
\stackrel{m}{E} \\
0 \\
\frac{0}{\infty}\end{array}$ & בิ & 旁 & 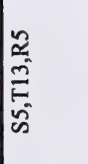 & 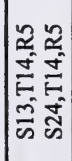 & 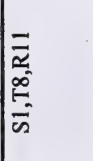 & 昰 & 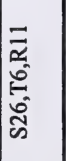 & 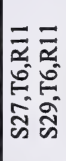 & 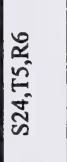 & 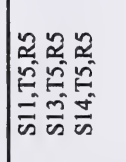 \\
\hline 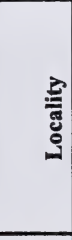 & 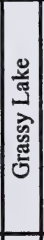 & 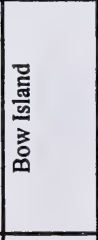 & 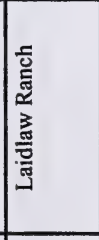 & 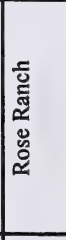 & 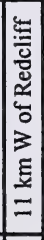 & 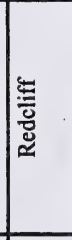 & 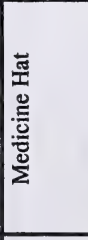 & 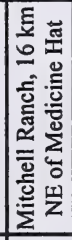 & 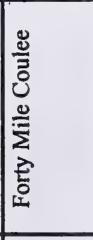 & 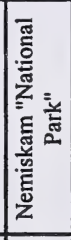 & 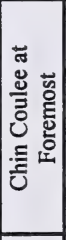 & 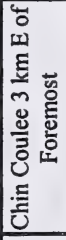 & 宽 & 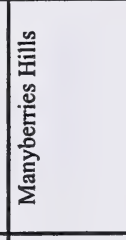 \\
\hline$\overline{\mathrm{e}}$ & 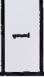 & $N$ & m & \& & in & 6 & In & 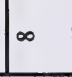 & 19 & $1-$ & $1-$ & & $1-$ & $=$ \\
\hline
\end{tabular}




\begin{tabular}{|c|c|c|c|c|c|c|c|c|c|c|c|c|c|c|c|c|}
\hline 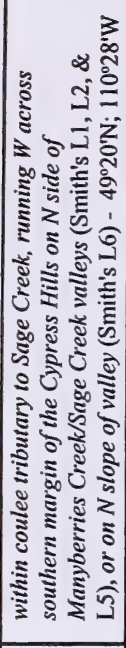 & 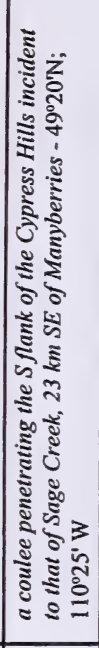 & 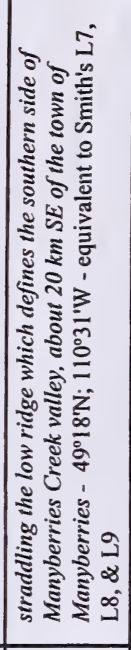 & 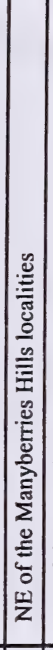 & 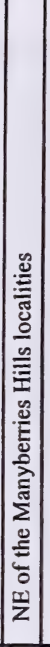 & 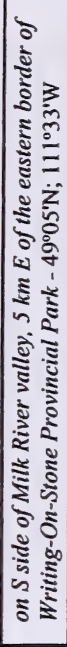 & 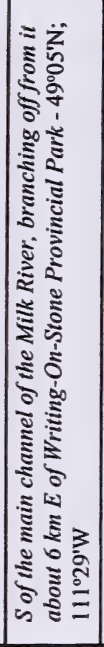 & 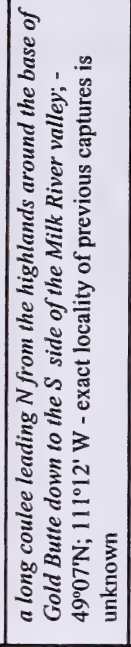 & 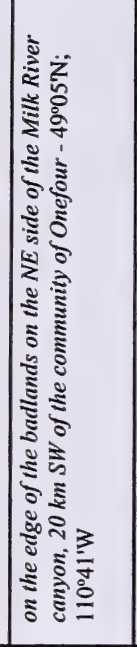 & 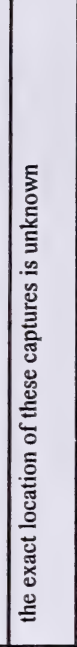 & 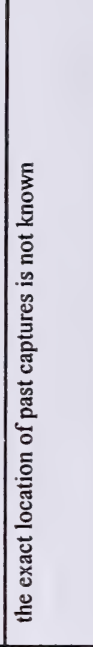 & 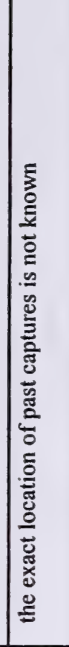 & 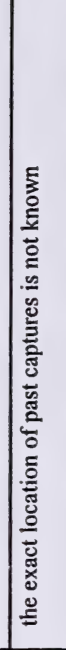 & 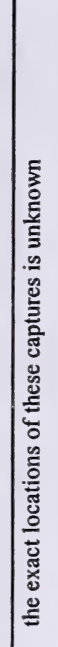 & 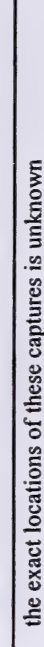 & & 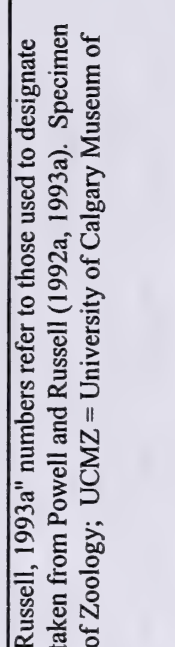 \\
\hline 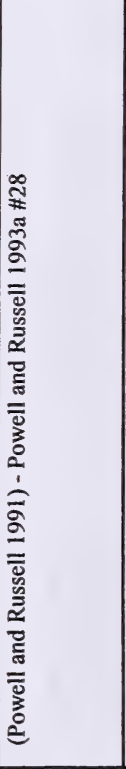 & 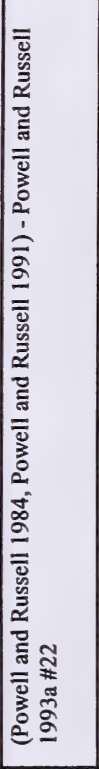 & 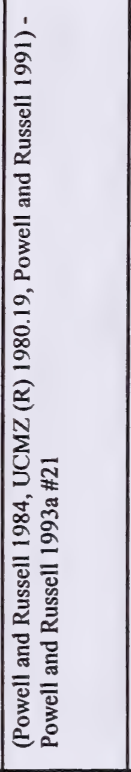 & 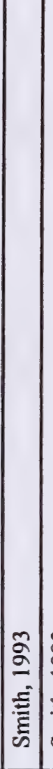 & 合 & 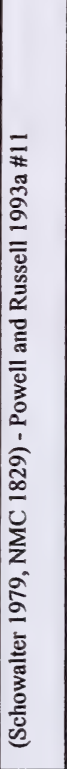 & 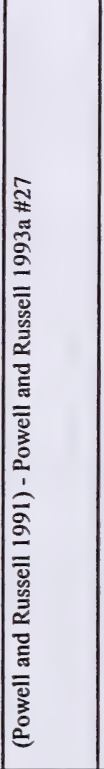 & 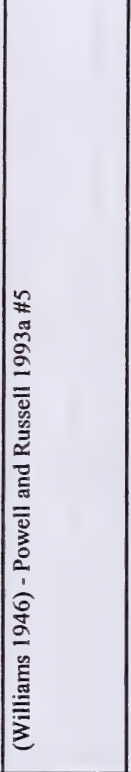 & 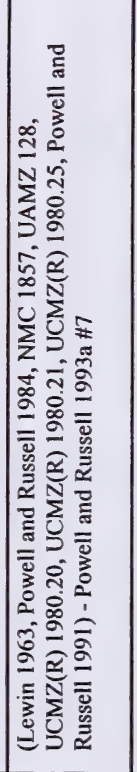 & 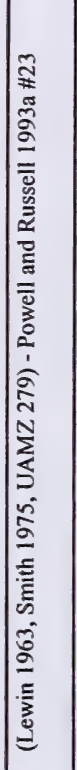 & 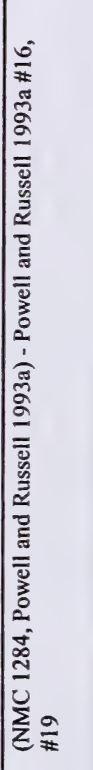 & 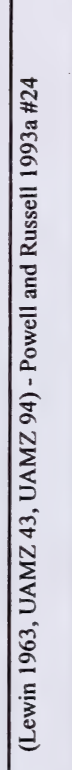 & 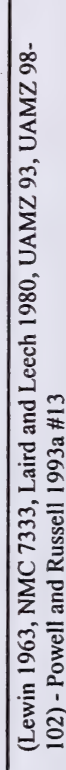 & 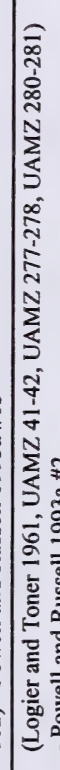 & 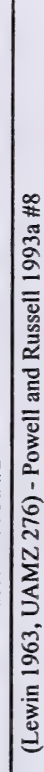 & & 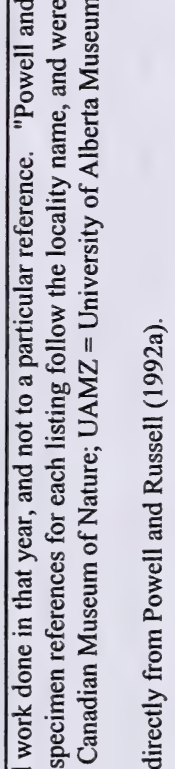 \\
\hline 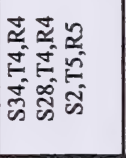 & 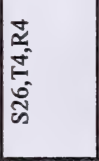 & 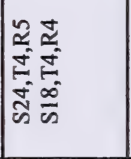 & 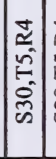 & 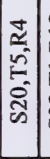 & 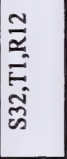 & 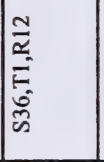 & 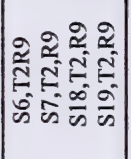 & 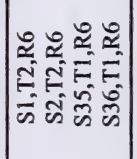 & 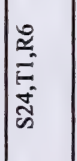 & 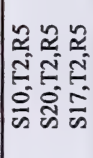 & שู & 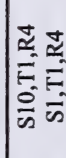 & $\mid$\begin{tabular}{l}
$\tilde{n}$ \\
\hdashline \\
\hdashline
\end{tabular} & & & 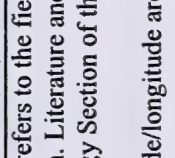 \\
\hline 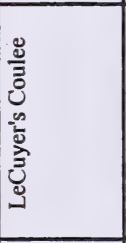 & 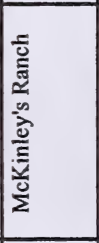 & 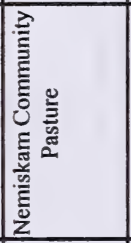 & 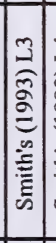 & 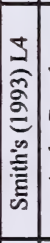 & 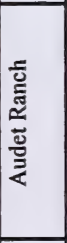 & 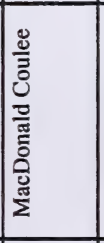 & $\frac{\overline{0}}{3}$ & ठ̀. & 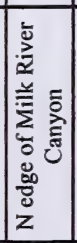 & 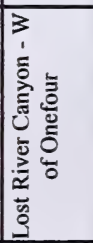 & 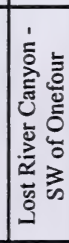 & 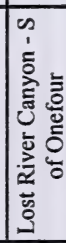 & 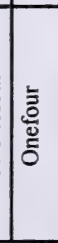 & 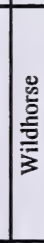 & & 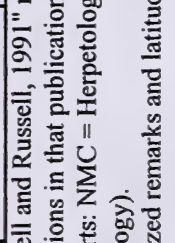 \\
\hline$\Xi$ & $\cong$ & 10 & $=$ & 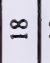 & 2 & సి & I & ส & $\sqrt{4}$ & $\sim$ & in & i & $I^{2}$ & $\sim$ & & $\cong 0 N \Phi$ \\
\hline
\end{tabular}




\section{List of Titles In This Series}

(as of September 1997)

No. 1 Status of the Piping Plover (Charadrius melodus) in Alberta, by David R. C. Prescott. 19 pp.

No. 2 Status of the Wolverine (Gulo gulo) in Alberta, by Stephen Petersen. $17 \mathrm{pp}$.

No. 3 Status of the Northern Long-eared Bat (Myotis septentrionalis) in Alberta, by M. Carolina Caceres and M. J. Pybus. 19 pp.

No. 4 Status of the Ord's Kangaroo Rat (Dipodomys ordii) in Alberta, by David L. Gummer. 16 pp.

No. 5 Status of the Eastern Short-horned Lizard (Phrynosoma douglassii brevirostre) in Alberta, by Janice D. James, Anthony P. Russell and G. Lawrence Powell. 20 pp.

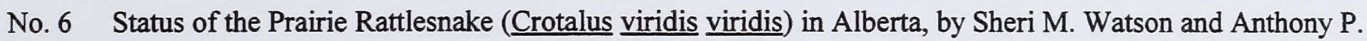
Russell. 26 pp.

No. 7 Status of the Swift Fox (Vulpes velox) in Alberta, by Susan E. Cotterill. 17pp.

No. 8 Status of the Peregrine Falcon (Falco peregrinus anatum) in Alberta, by Petra Rowell and David P. Stepnisky. In Preparation.

No. 9 Status of the Northern Leopard Frog (Rana pipiens) in Alberta, by Greg Wagner. In Preparation.

No. 10 Status of the Sprague's Pipit (Anthus spragueii) in Alberta, by David R. C. Prescott. 14 pp.

No. 11 Status of the Burrowing Owl (Speotyto cunicularia hypugaea) in Alberta, by Troy I. Wellicome. $21 \mathrm{pp}$. 


\section{NOTES}


National Library of Canada Bibliotheque nationale du Canada

33286513566915 